\title{
Effects of Zinc Sources and Levels on Growth Performance, Zinc Status, Expressions of Zinc Transporters, and Zinc Bioavailability in Weaned Piglets
}

\author{
Xin Ma ${ }^{1}{ }^{1}$, Mengqi Qian ${ }^{1}$, Zhiren Yang ${ }^{1,2}$, Tingting $\mathrm{Xu}^{1}$ and Xinyan Han ${ }^{1,2, *}$ \\ 1 Key Laboratory of Animal Nutrition and Feed Science in East China, Ministry of Agriculture, College of \\ Animal Science, Zhejiang University, Hangzhou 310058, China; xinma@zju.edu.cn (X.M.); \\ 22017017@zju.edu.cn (M.Q.); 22017080@zju.edu.cn (Z.Y.); 22017016@zju.edu.cn (T.X.) \\ 2 Hainan Institute of Zhejiang University, Yazhou Bay Science and Technology City, Yazhou District, \\ Sanya 572025, China \\ * Correspondence: xyhan@zju.edu.cn; Tel.: +86-571-88982446; Fax: +86-571-88982650
}

Citation: Ma, X.; Qian, M.; Yang, Z.; Xu, T.; Han, X. Effects of Zinc Sources and Levels on Growth Performance, Zinc Status, Expressions of Zinc Transporters, and Zinc Bioavailability in Weaned Piglets. Animals 2021, 11, 2515. https://doi.org/10.3390/ ani11092515

Academic Editor: Raffaella Rossi

Received: 23 July 2021

Accepted: 25 August 2021

Published: 26 August 2021

Publisher's Note: MDPI stays neutral with regard to jurisdictional claims in published maps and institutional affiliations.

Copyright: (C) 2021 by the authors Licensee MDPI, Basel, Switzerland. This article is an open access article distributed under the terms and conditions of the Creative Commons Attribution (CC BY) license (https:// creativecommons.org/licenses/by/ $4.0 /)$.
Simple Summary: Bioavailability of inorganic zinc in animals is low, and large amounts of zinc are excreted into feces, resulting in potential negative impacts on the environment and waste of zinc resources. To reduce zinc supplementation in animal feed, prepared and characterized chitosan-zinc (CS-Zn) chelate was studied to investigate its bioavailability. Dietary CS-Zn improved the weight gain of weaned piglets as compared to $\mathrm{ZnSO}_{4}$. The $\mathrm{Zn}$ source had a significant influence on the liver, pancreas $\mathrm{Zn}$ contents, and the protein expression of ZnT1 and ZIP5 in duodenal mucosa. The Zn contents in the liver and pancreas and the protein expressions of ZnT1 and ZIP5 increased linearly with increases in the added $\mathrm{Zn}$ level. Multiple linear regression and the slope-ratio methodology showed that the bioavailability of CS-Zn was $110.9 \%$ or $149.0 \%$ relative to $\mathrm{ZnSO}_{4}$, respectively, using zinc content in the liver or pancreas as the response parameter. These results indicate that CS-Zn shows enhanced bioavailability, suggesting a good potential substitute for inorganic zinc in animal nutrition.

Abstract: The present study was conducted to explore the bioavailability of chitosan-zinc chelate (CS-Zn) in weaned piglets, and its characteristics of prepared and oral safety were also involved. A total of 210 crossbred weaned piglets (Duroc $\times$ Landrace $\times$ Large White) with a mean body weight of $6.30 \mathrm{~kg}$ were randomly assigned into seven dietary treatments involving a $2 \times 3$ factorial arrangement with two $\mathrm{Zn}$ sources (CS-Zn and $\mathrm{ZnSO}_{4}$ ) and three levels of added $\mathrm{Zn}$ (50, 100, $150 \mathrm{mg} \mathrm{Zn} / \mathrm{kg}$ ) plus a $Z n$-unsupplemented control diet. The feeding trial lasted 42 days. The AFM image of CS-Zn showed a rougher appearance and smaller size particles. The changes in spectrum peaks evidenced the successful chelating of $\mathrm{Zn}^{2+}$ with chitosan. The XRD patterns revealed the formation of a new crystalline phase. Moreover, the oral acute toxicity test of CS-Zn showed no lethal effects on mice. Weaned piglets fed dietary CS-Zn showed improved weight gain and decreased diarrhea incidence. Additionally, the bioavailability of CS-Zn was higher than that of $\mathrm{ZnSO}_{4}$ in piglets. Taken together, these results indicate that the prepared CS-Zn chelate, with rough surface and crystalline phase, is non-toxic and show enhanced bioavailability.

Keywords: chitosan-zinc chelate; bioavailability; zinc transporter protein; weaned piglets

\section{Introduction}

In recent years, heavy metal excretion from pig production has received more and more attention from the public due to its potential negative impacts on the environment and human health. In animal science, zinc is usually supplemented into the feed to improve performance as an inorganic form $\left(\mathrm{ZnO}\right.$ or $\left.\mathrm{ZnSO}_{4}\right)$. In order to lessen diarrhea and improve performance in weaned piglets, the common recommendations are $1000-4000 \mathrm{mg} \mathrm{kg}^{-1}$ of inorganic Zn [1]. Notice No. 2625 of the Ministry of Agriculture of China stipulates that 
the supplemental amount of zinc in the form of $\mathrm{ZnO}$ in the compound feed of piglets for the first 2 weeks after weaning should not exceed $1600 \mathrm{mg} \mathrm{kg}^{-1}$. However, according to the National Research Council (NRC, 2012) [2], the requirement for zinc supplementation in the feed of weaned piglets is $60-100 \mathrm{mg} \mathrm{kg}^{-1}$. The abusive use of zinc additive in livestock husbandry is still serious, and large amounts of zinc are excreted into feces due to the low bioavailability of $\mathrm{ZnO}$ or $\mathrm{ZnSO}_{4}$, resulting in soil and river contamination [3] and a huge waste of zinc resources [4]. It is made even more worrying that enteral bacteria in food-producing animals may develop antibiotic resistance due to high dose trace elements supplementation such as zinc, while such bacteria carrying resistance genes may be transferred from animals to humans [5]. Studies have shown that organic zinc is a potential alternative for inorganic zinc to reduce zinc excretion [6]. Therefore, zinc from different sources, which have higher bioavailability, have attracted researchers' interests.

Chitosan (CS) is a deacetylated derivative of chitin, containing a large number of amine groups and hydroxyl groups. This structure brings tremendous capability to chelate metals and form CS-metal complexes [7]. Therefore, one of the essential properties of chitosan is its capability to chelate powerfully with heavy metal ions, especially with $\mathrm{Zn}, \mathrm{Cu}, \mathrm{Hg}$, $\mathrm{Pb}, \mathrm{Cr}$, and so on. Various previous applications proposed were in water purification for wiping off toxic metal ions or other ions [8]. Chitosan also plays an important role in antibacterial activity and protection against pathogenic infections $[9,10]$. Recently, several kinds of chitosan derivatives were studied as carriers for therapeutic proteins and on disease therapies [11]. In addition, there are many hybrids, which consist of chitosan and some substance (such as zeolite, granular activated carbon, etc.), could exert better function in varied areas.

Chitosan-Zn chelate (CS-Zn) is a chelate of $\mathrm{Zn}^{2+}$ with CS. After CS binding to $\mathrm{Zn}$ ions through oxygen, nitrogen, or the combination of them, it will probably have better biological activity [12]. Our previous studies showed that dietary chitosan-zinc chelate could not only reduce post-weaning diarrhea and increase growth performance but also improve the intestinal structure in weaned piglets. Moreover, dietary $100 \mathrm{mg} \mathrm{kg}^{-1} \mathrm{Zn}$ as CS-Zn was discovered to have similar biological effects to dietary $3000 \mathrm{mg} \mathrm{kg}^{-1} \mathrm{Zn}$ as $\mathrm{ZnO}$ [13], implying that CS-Zn might be a kind of novel source of zinc in pig production.

The evaluation on the characteristics, safety, and bioavailability of CS-Zn chelate is important for its potential applications in food, feed additives, and health care products. Therefore, we hypothesized that dietary CS-Zn would show higher bioavailability and less zinc content of feces in pig production. The present study dealt with (1) the characteristic of prepared CS-Zn through several physical methods including atomic force microscopy (AFM), Fourier transform infrared (FT-IR), and X-ray diffraction (XRD), (2) the oral acute toxicity of CS-Zn on mice, and (3) the assessment of its bioavailability in weaned piglets by using the concentration of zinc in the liver and pancreas as indicators.

\section{Materials and Methods}

\subsection{Materials}

Chitosan, MW 40,000-50,000 and 95\% degree of deacetylation, was acquired from Gold Shell biochemical Co. Ltd. (Taizhou, China). $\mathrm{ZnSO}_{4} \cdot 7 \mathrm{H}_{2} \mathrm{O}$, acetic acid, absolute ethyl alcohol, and acetone were analytical grade chemicals. All the reagents were used without further purification.

\subsection{Preparation of $\mathrm{CS}-\mathrm{Zn}$ Chelate}

The chelate was prepared as follows: Chitosan $(3 \mathrm{~g})$ was dissolved in approximately $2 \mathrm{~mL}$ acetic acid (AR) by continuously stirring on the magnetic stirrer. During the stirring, an amount of zinc sulphate (v:v = 4:1) was added into the solution. We continued stirring until the mixture was homogeneous. AR and water were added to maintain the $\mathrm{pH}$ value around 5. After being stirred for $8 \mathrm{~h}$ on the magnetic stirrer, the mixture was poured into absolute ethyl alcohol and acetone solution (1:1). Then, the supernatant was discarded and the white 
precipitate was washed with distilled water several times until there was no $\mathrm{Zn}^{2+}$ in eluent. Finally, the precipitates were kept at $60{ }^{\circ} \mathrm{C}$ for about $10 \mathrm{~h}$ and, then, cooled to $25^{\circ} \mathrm{C}$.

\subsection{Characterization}

\subsubsection{Atomic Force Microscopy Analysis}

Surface structure was measured by SPM-9500J3 atomic absorption spectrometry (AFM, Shimadzu Corporation, Kyoto, Japan). Chitosan-Zn chelate was sonicated for $10 \mathrm{~min}$ to facilitate dissolution and properly diluted in distilled water. The stock solutions were diluted with $10 \mathrm{mM}$ ammonium bicarbonate buffer ( $\mathrm{pH} 8$ ) to a final concentration of $1-5 \mu \mathrm{g} \mathrm{mL}{ }^{-1}$. Then, 10 microliters samples were drop-deposited onto freshly cleaved sheets of mica. The coated mica preparations were air-dried on a heating block at $37^{\circ} \mathrm{C}$, promoting homogeneous spreading of the sample across the mica, reducing molecular aggregation on drying and subliming off the buffer [14]. After drying, the sample was moved onto the AFM.

\subsubsection{Fourier Transform Infrared Analysis}

FT-IR spectra were collected in the absorbance mode in the frequency range of $400-4000 \mathrm{~cm}^{-1}$ using an AVATAR 370 spectrophotometer (Perkin Elmer, Waltham, MA, USA). The samples were mixed uniformly with potassium bromide in a 1:5 ratio (sample: $\mathrm{KBr}$ ). The $\mathrm{KBr}$ discs were equipped by condensing the mixed powders at a pressure of 5 tons for $5 \mathrm{~min}$ in a hydraulic press. The discs were scanned in the parameters of $400-4000 \mathrm{~cm}^{-1}$ to acquire FT-IR spectra.

\subsubsection{X-ray Diffraction Analysis}

Identification of the crystal phases was executed by $\mathrm{X}$-ray diffraction analysis. The $\mathrm{XRD}$ patterns were acquired by Bruker-AXS D8 Advance, with Cu Ka radiation $(\lambda=0.154 \mathrm{~nm})$ at $40 \mathrm{kV}$ and $30 \mathrm{~mA}$. X-ray diffraction data were obtained from $2 \theta=5-35^{\circ}$ at a scanning rate of $0.5^{\circ} / \mathrm{s}$ at room temperature.

\subsection{Oral Acute Toxicity in Mice}

Animal testing was approved by the Experimental Animal Center of Zhejiang Province (SCXK 2014-0001). All experimental procedures involving animal care and sampling were performed with compliance of the institutional guidelines for animal research. Fifty ICR mice, weighing 18-22 g, male and female each half were purchased from Shanghai laboratory animal Center (Shanghai, China). The mice were housed by sex and fed on commercial pellet diet, given deionized water ad libitum, and kept in plastic cages in a $21-26{ }^{\circ} \mathrm{C}$ controlled temperature, $50-70 \%$ relative humidity room. After three-day acclimation, the mice were fasted over night before the experiments and were divided into 5 groups of 5 male and 5 females at random. The animals were treated with each dose level of CS-Zn (2.15, $\left.4.64,10.0,21.5,46.4 \mathrm{~g} \mathrm{~kg}^{-1}\right)$, respectively. Toxins CS-Zn $\left(1.08,2.32,5.0,10.76 \mathrm{~g} \mathrm{~kg}^{-1}\right)$, dissolved in soybean oil to $20 \mathrm{~mL}$, were given to mice by gastric gavage at twice in a volume of $0.2 \mathrm{~mL} \mathrm{~kg}^{-1}$ body weight. While the $46.4 \mathrm{~g} \mathrm{~kg}^{-1}$ group were administrated with CS-Zn (11.6 g in $20 \mathrm{~mL}$ soybean oil) at third times. All the mice were weighed before the treatment and after death immediately. After gavage of the toxins, mice were observed daily for 2 weeks and the signs of general health status, toxic symptoms, and mortality were recorded. After two-week treatment, the animals were sacrificed for histopathological examination. The $\mathrm{LD}_{50}$ values (lethal dose of the toxins for $50 \%$ of the treated mice), based on $24 \mathrm{~h}$ mortality data, were calculated at $95 \%$ confidence level.

\subsection{Bioavailability Analysis in Piglets}

\subsubsection{Animal Treatment}

The present study followed the institutional guidelines for the care and use of animals. All the animals and samples designed for the experiment were certified by the Animal Care and Use Committee of Zhejiang University (SYXK 2012-0178). 
A total of 210 crossbred weaned piglets (Duroc $\times$ Landrace $\times$ Large White), aged 21 days and weighing about $6.30 \mathrm{~kg}$, were randomly assigned to 7 dietary treatments, and each treatment was replicated 3 times with 10 piglets per replicate. The group fed a corn-soybean meal basal diet (Table 1) without extra Zn supplementation was applied as control. Compared to the control, the other 6 dietary treatments were fed a basal diet supplemented with $50 \mathrm{mg} \mathrm{kg}^{-1}$ of $\mathrm{Zn}$ as $\mathrm{ZnSO}_{4}, 100 \mathrm{mg} \mathrm{kg}^{-1}$ of $\mathrm{Zn}$ as $\mathrm{ZnSO}_{4}, 150 \mathrm{mg} \mathrm{kg}^{-1}$ of $\mathrm{Zn}$ as $\mathrm{ZnSO}_{4}, 50 \mathrm{mg} \mathrm{kg}^{-1}$ of $\mathrm{Zn}$ as CS-Zn, $100 \mathrm{mg} \mathrm{kg}^{-1}$ of $\mathrm{Zn}$ as CS-Zn, and $150 \mathrm{mg} \mathrm{kg}^{-1}$ of $\mathrm{Zn}$ as CS-Zn, respectively. CS-Zn, a Zn-chitosan chelate compound, was provided by the Zhejiang University Feed Science Institute (Hangzhou, China), and the content of $\mathrm{Zn}$ was $16.7 \%$. Basal diet was formulated in accordance with the nutrient requirements recommended for weaned piglets by NRC (2012) [2]. The analyzed Zn contents in diets were presented in Table S1.

Table 1. Composition and nutrient levels of basal diet (as-fed basis).

\begin{tabular}{cccc}
\hline Ingredients & $\mathbf{\%}$ & Nutrient Levels $^{\mathbf{2}}$ & Content \\
\hline Corn & 62 & Digestible energy, MJ/kg & 13.75 \\
Soybean meal & 16 & Crude protein, \% & 18.12 \\
Extruded soybeans & 7 & Ether extract, \% & 3.26 \\
Fish meal & 4 & Calcium, \% & 0.93 \\
Whey powder & 5 & Phosphorus, \% & 0.79 \\
Bran & 2 & Zinc, mg $/ \mathrm{kg}$ & 47.30 \\
Salt & 0.4 & & \\
Calcium hydrogen phosphate & 1.1 & & \\
Limestone $_{\text {Premix }}{ }^{1}$ & 1.5 & & \\
\hline
\end{tabular}

${ }^{1}$ Contained the following per kg of diet: $\mathrm{Cu} 120 \mathrm{mg}\left(\mathrm{CuSO}_{4} \cdot 5 \mathrm{H}_{2} \mathrm{O}\right), \mathrm{Fe} 400 \mathrm{mg}\left(\mathrm{FeSO}_{4} \cdot 7 \mathrm{H}_{2} \mathrm{O}\right), \mathrm{Mn} 60 \mathrm{mg}$ $\left(\mathrm{MnSO}_{4} \cdot 4 \mathrm{H}_{2} \mathrm{O}\right)$, VA $1000 \mathrm{IU}$, VD $200 \mathrm{IU}, \mathrm{VE} 60 \mathrm{mg}, \mathrm{VB}_{12} 10 \mathrm{mg}, \mathrm{VB}_{1} 1 \mathrm{mg}, \mathrm{VB}_{6} 2 \mathrm{mg}$, choline $500 \mathrm{mg}$, pantothenate acid $10 \mathrm{mg}$, niacin $35 \mathrm{mg} ;{ }^{2}$ digestible energy was calculated values and others were measured values.

The piglets were given free access to feed and water throughout the experiment (42 days). Piglets were weighed at the start and the end of the feeding experiment individually to calculate the average daily gain (ADG). Feed intake was recorded daily per pen to calculate the average daily feed intake (ADFI), then feed to gain ratios $(\mathrm{F} / \mathrm{G})$ were calculated for each pen. Mortality was considered in the calculations of ADG and ADFI. Diarrhea incidents, feces consistency, and color were recorded every day. Diarrhea index was scored as follows: 0, normal feces (solid); 1, moist feces (semi-solid); 2, mild diarrhea (loose feces); 3 , severe diarrhea (watery feces). Mild diarrhea and severe diarrhea were both considered as diarrhea. The number of weaned piglets suffering from diarrhea and its duration were monitored and recorded during the experiment. The rate of diarrhea was calculated as the total number of weaned piglets with diarrhea multiplied by number of days of diarrhea divided by the total number of piglets multiply duration of feeding experiment.

\subsubsection{Sample Collection}

At the end of the feeding experiment, 6 piglets ( 2 piglets per pen) from each dietary treatment were selected randomly to be euthanized after a $12-\mathrm{h}$ fast. Liver and pancreas samples were excised and stored at $-80{ }^{\circ} \mathrm{C}$ until analysis. Duodenal mucosa was stripped from the seromuscular layer, transferred to Eppendorf tubes, snap-frozen in liquid nitrogen and stored at $-80^{\circ} \mathrm{C}$. Fecal samples were collected by using total feces collection method from each treatment on the 40,41, 42 days, mixed and homogenized with 10\% hydrochloric acid and stored in a refrigerator at $-20^{\circ} \mathrm{C}$.

\subsubsection{Zinc Content and Transporter Analysis}

After being wet digested with nitric acid via microwave, the zinc concentrations in the liver, pancreas, and feces were measured by an atomic absorption spectrophotometer (Thermo Scientific M5 AA Spectrometer, Waltham, MA, USA). 
The protein expressions of Slc 30 A 1 Zinc Transporter (ZnT1) and Slc 39 A 5 Zinc Transporter (ZIP5) in the intestine were detected by Western blot. The total proteins were extracted by the total protein extractive kit containing protease inhibitor cocktail (Haoji Biotechnology, Hangzhou, China) and, then, detected by a BCA protein quantitative kit (Haoji Biotechnology, Hangzhou, China). Protein was separated by SDS-PAGE and transferred onto PVDF membrane (Millipore, MA, USA). The membranes were closed in $5 \%$ non- fat milk powder for $1 \mathrm{~h}$. After several washes, the membranes were incubated with a 1:500 dilution of anti-ZnT1 antibody (Santa cruz SC-27501) or anti-Zip5 antibody (abcam ab76191) at $4{ }^{\circ} \mathrm{C}$ overnight. Similarly, after several washes, each membrane was dissolved in $2 \%$ non-fat milk powder for $1 \mathrm{~h}$. According to the manufacturer's protocol (Super Signal), the signals were estimated by West Dura Extended Duration Substrate. In the end, the data were analyzed by Bandscan software system (v5.0) and presented as the mean and standard deviation.

\subsection{Statistical Analysis}

To explore the effect supplemental $\mathrm{Zn}$, data were analyzed by using a single degree of freedom contrast to compare all supplemental $\mathrm{Zn}$ treatments with the control. Dates excluding the control were further analyzed as $2 \times 3$ (source $\times$ level) factorial arrangement of treatments by two-way ANOVA using the general linear model (GLM) procedure (IBM SPSS Statistics 20). The model included the main effects of supplemental $\mathrm{Zn}$ level and source, as well as their interaction. When an effect was significant, means were compared by the least significant difference (LSD) method to determine specific differences between means. Orthogonal polynomials were applied to judge linear responses of dependent variables to daily intake amount of dietary analyzed $\mathrm{Zn}$. Inputting the concentration of Zinc in the liver, pancreas as dependent variable, and the addition of CS- $\mathrm{Zn}$ or $\mathrm{ZnSO}_{4}$ as independent variable, the statistical model was as follow: $Y=c+a X_{1}+b X_{2}$, where $\mathrm{X}_{1}$ is the addition of CS-Zn in daily diet and $\mathrm{X}_{2}$ is the addition of $\mathrm{ZnSO}_{4}$ in daily diet. According to the standard of inorganic zinc sulfate (100\%), the bioavailability of CS-Zn relative to $\mathrm{ZnSO}_{4}$ was calculated by using the multiple linear regression slope ratio method, equaling to $a / b^{*} 100 \%$. When the probability of an independent variable's t-value was less than 0.01 , the effect of $X_{1}$ and $X_{2}$ on the dependent variable was significant. The square of $\mathrm{R}$ was presented as the degree to which the dependent variable is dependent on the independent variable. The collected data were analyzed and expressed as mean \pm SD. Statistical significance was determined at $p<0.05$.

\section{Results and Discussion}

\subsection{Atomic Force Microscopy Analysis}

Atomic force microscopy is usually used to exam the surface image. The threedimensional AFM image of CS and CS-Zn were shown in Figure 1. Figure 1A,B is shown over an area of $6250 \mathrm{~nm}^{-1}$. The particles of CS distributed regularly. The morphology of particles was a ball or ellipsoid shape. The surfaces of CS samples had typical hills and valleys morphology with a smooth surface. However, the AFM image of CS-Zn consisted of flakes growing on the entire surface and showed a rougher appearance, which was different from that of CS. Moreover, the size of CS-Zn was smaller than that of CS. 
A

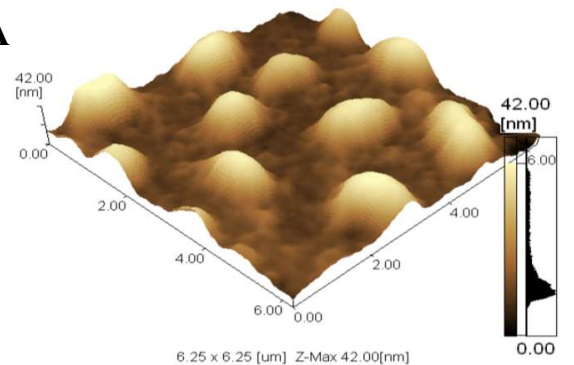

C
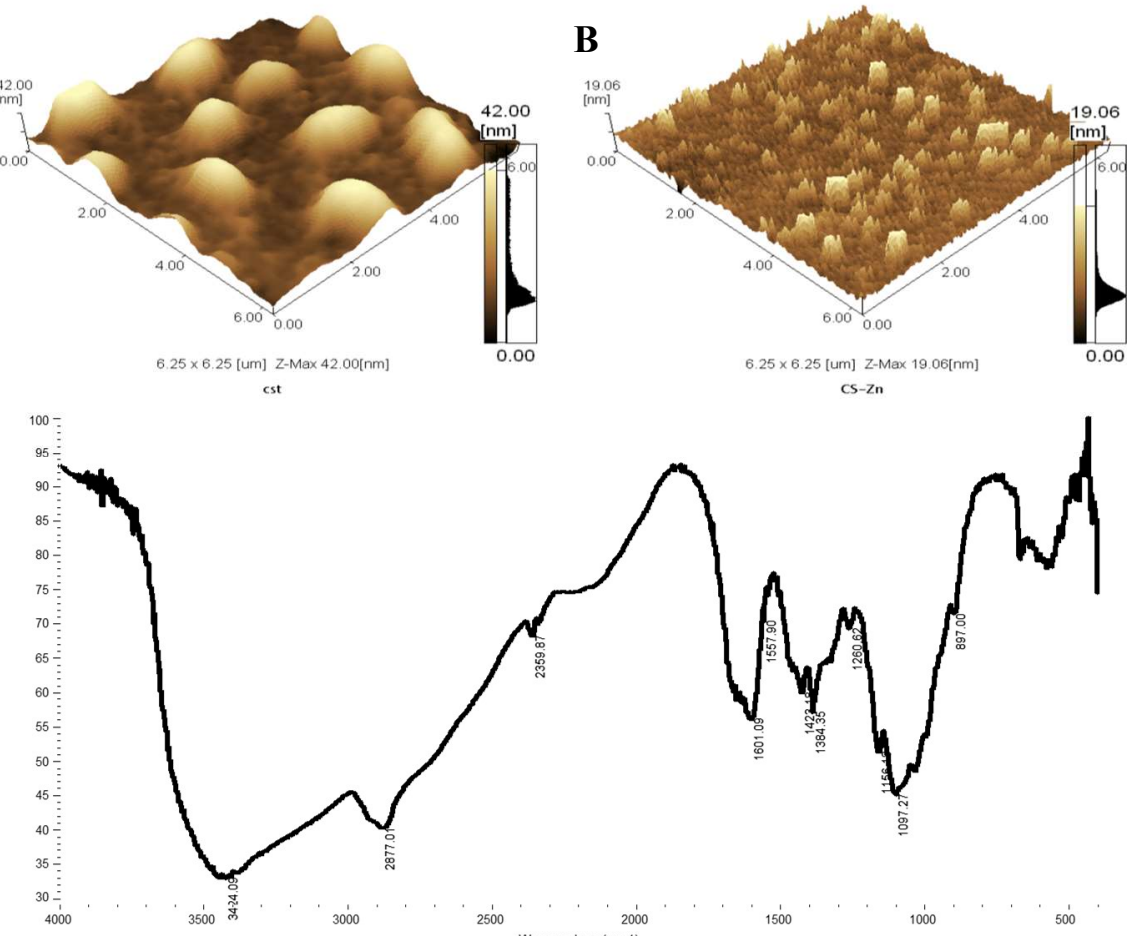

CS-Zn

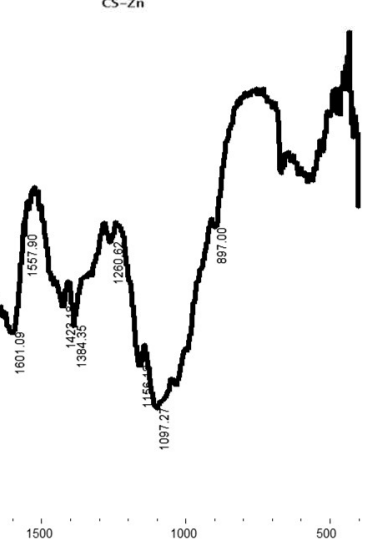

\section{D}

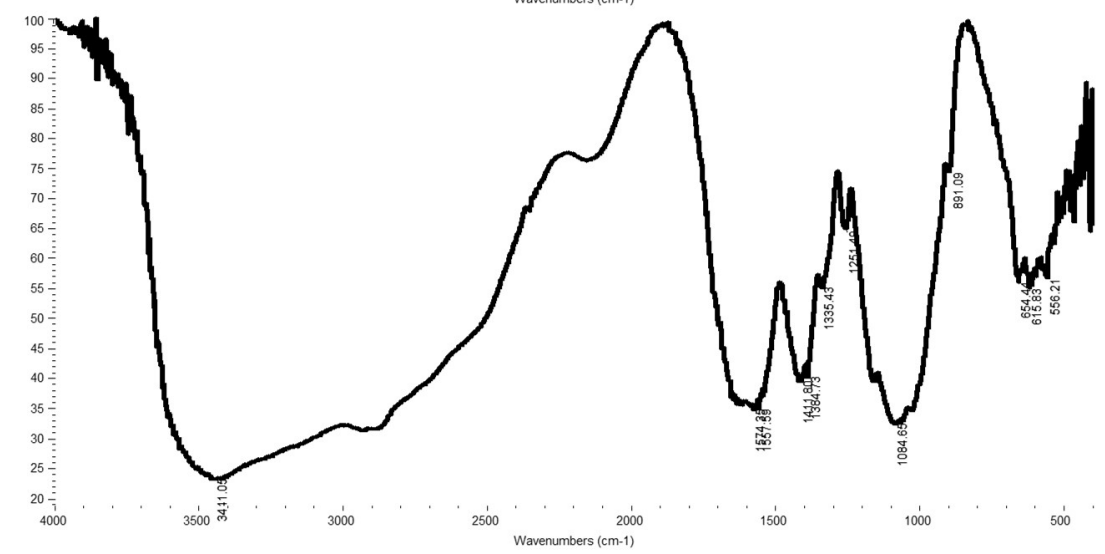

$\mathbf{E}$

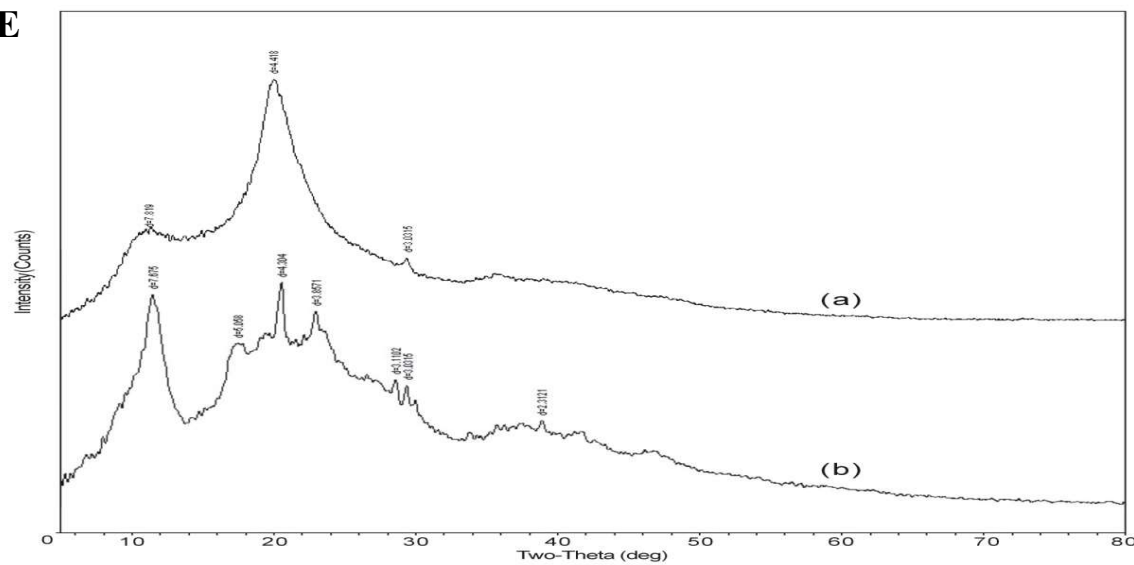

Figure 1. (A) AFM images of chitosan. (B) AFM images of chitosan-zinc chelate. (C) FT-IR spectrum of chitosan. (D) FT-IR spectrum of chitosan-zinc chelate. (E) X-ray diffractogram of (a) chitosan, (b) chitosan-zinc chelate.

The significant change in the structure of CS-Zn might potentially be the existence of $-\mathrm{NH}_{2}$ group and $-\mathrm{OH}$ group, as the metal-chelating ligand bonded with mineral impeccably. In other words, metal ions such as $\mathrm{Zn}^{2+}$ were very strongly bound to the chitosan. 


\subsection{Fourier Transform Infrared Analysis}

FTIR analysis was used to verify the characteristic functional groups on the surface of CS-Zn chelate. The obtained FT-IR spectrum of CS and CS-Zn were shown in Figure 1C,D. Firstly, the FT-IR spectrum of CS-Zn consisted of a number of sharp absorptions consisted with a well-defined molecular structure. Secondly, the FT-IR spectrum of CS-Zn chelate showed some variations from that of CS. The band peak at $3424.09 \mathrm{~cm}^{-1}$, corresponding to the multiple absorption peaks, was developed by stretching vibration of the $-\mathrm{NH}_{2}$ group and -OH group as well as inter- and intra-molecular hydrogen bonding. However, these peaks became weak and shifted to low frequency, which was as similar as the results reported by Saeed et al. (2014) [15]. These were ascribed to the interaction between chitosan and ions. The asymmetric stretching of $\mathrm{CH}_{3}$ and $\mathrm{CH}_{2}$ of chitosan polymerat developed a peak at $2359.87 \mathrm{~cm}^{-1}$, which was nearly with the results observed by Guo et al. (2005) [16]. However, it disappeared when $\mathrm{Zn}^{2+}$ was added, which was consistent with the studies showed by AbdElhady (2012) [17]. The absorb bands at $1601.09 \mathrm{~cm}^{-1}$ (a sign of $-\mathrm{NH}_{2}$ group and at $1384.35 \mathrm{~cm}^{-1}$ (a sign of $-\mathrm{OH}$ group) both clearly shifted to a lower wavenumber. These implied that the $-\mathrm{OH}$ group and $-\mathrm{NH}_{2}$ group were involved in this reaction [18]. Therefore, the successful chelating of $\mathrm{Zn}^{2+}$ onto the CS was evidenced by the changes in the peaks of CS-Zn.

\subsection{X-ray Diffraction Analysis}

Figure 1E showed the XRD pattern of the CS (a) and CS-Zn (b). A broad diffraction peak between $10^{\circ}$ and $30^{\circ}$ was observed in the XRD pattern of the CS-Zn, while the XRD pattern of the CS only showed two characteristic peaks at $10.5^{\circ}$ and $21.1^{\circ}$, which were corresponding to $d(7.819)$ and $d(4.418)$, respectively. This result was agreed with the study reported by Li et al. (2010) [19]. However, both of them were weakened, which might be attributed to $\mathrm{Zn}^{2+}$ disturbing (or impeding) the order of the polymer chain [18]. Even some imaging observed the second characteristic peak disappeared [20]. Obviously, CS chelated with $\mathrm{Zn}^{2+}$ showed more numerous and sharper X-ray diffraction bands than that of untreated CS. This indicated that the complexes obtained by chelation had a single crystalline phase. The pattern was consistent with the study of Wang et al. (2004) [12], revealing the formation of a new crystalline phase.

\subsection{Oral Acute Toxicity in Mice}

The results of oral acute toxicity of CS-Zn were shown in the Table S2. The data indicated that oral administration of CS-Zn would be placed in the category of least concern, "relatively harmless". It also showed that the death of mice gavaged with CS-Zn occurred starting from the dose of $10.0 \mathrm{~g} \mathrm{~kg}^{-1} \mathrm{CS}-\mathrm{Zn}$. Mice treated with each dose (except $2.15 \mathrm{~g} \mathrm{~kg}^{-1}$ group) of the samples were apathetic, piloerection, and clustering in one hour. However, the mice treated with $21.5 \mathrm{~g} \mathrm{~kg}^{-1}$ or $46.4 \mathrm{~g} \mathrm{~kg}^{-1}$ subsequently recovered within $30 \mathrm{~min}$ to an apparently normal state. After that, no mortality and symptoms were observed during the two-week experimental period. On the contrary, all the mice treated with the maximum dose $\left(46.4 \mathrm{~g} \mathrm{~kg}^{-1}\right)$ were dead after the second time of gastric gavage. Furthermore, no obvious differences were found in the final body weight of the three treatments. The $\mathrm{LD}_{50}$ values (dose causing lethality in $50 \%$ of treated mice) for female and male mice were both $10.08 \mathrm{~g} \mathrm{~kg}^{-1}$. These results indicated that there were no differences between female and male mice. The $\mathrm{LD}_{50}$ values showed that CS-Zn did not result in pathological symptoms and lethal effects of mice according to the acute toxic classifications of WHO criteria.

\subsection{Bioavailability Analysis}

Growth performance of weaned piglets affected by dietary Zn source and level was shown in Table 2. Zn source, added $\mathrm{Zn}$ level, and their interaction between $\mathrm{Zn}$ source and added Zn level significantly affected ADG, ADFI, and F/G $(p<0.014)$. Compared with the piglet's diets supplemented with $\mathrm{ZnSO}_{4}$, the piglets fed diets supplemented with 
CS-Zn had higher ADG and ADFI and a lower F/G $(p<0.05)$. The piglets fed diets supplemented with $150 \mathrm{mg} \mathrm{kg}^{-1}$ of $\mathrm{Zn}$ had higher ADG and ADFI than those fed diets supplemented with either 50 or $100 \mathrm{mg} \mathrm{kg}^{-1}$ regardless of $Z$ n source $(p<0.01)$. Diarrhea incidence of weaned piglets fed dietary CS- $\mathrm{Zn}$ or $\mathrm{ZnSO}_{4}$ is presented in Figure 2A. The interaction between $\mathrm{Zn}$ source and added $\mathrm{Zn}$ level affected diarrhea incidence significantly. By adding $100 \mathrm{mg} \mathrm{kg}^{-1} \mathrm{Zn}$ as CS-Zn, $150 \mathrm{mg} \mathrm{kg}^{-1} \mathrm{Zn}$ as CS-Zn, and $150 \mathrm{mg} \mathrm{kg}^{-1} \mathrm{Zn}$ as $\mathrm{ZnSO}_{4}$, the diarrhea incidence of weaned piglets was obviously decreased, compared with control treatment $(p<0.01)$. Moreover, the piglets receiving $100 \mathrm{mg} \mathrm{kg}^{-1} \mathrm{Zn}$ as CS- $\mathrm{Zn}$ and $150 \mathrm{mg} \mathrm{kg}^{-1} \mathrm{Zn}$ as CS-Zn had a lower diarrhea incidence than that of the piglets fed the diets containing the same level of $\mathrm{ZnSO}_{4}(p<0.001)$. In CS- $\mathrm{Zn}$ treatment, the diarrhea incidence was significantly decreased with the increase in $\mathrm{Zn}$ level.

Table 2. Effects of dietary Zn source and level on the growth performance of weaned piglets.

\begin{tabular}{|c|c|c|c|c|}
\hline Item & Added Zn Level (mg kg-1) & $\operatorname{ADG}\left(\mathrm{g} \mathrm{d}^{-1}\right)$ & ADFI $\left(g^{-1}\right)$ & $F / G\left(g^{-1}\right)$ \\
\hline Control & 0 & $231.0 \pm 55.40$ & $480.9 \pm 13.6$ & $2.08 \pm 0.17$ \\
\hline \multirow[t]{3}{*}{$\mathrm{ZnSO}_{4}$} & 50 & $231.3 \pm 17.98^{\mathrm{Bb}}$ & $498.9 \pm 20.5^{\mathrm{Aa}}$ & $2.04 \pm 0.08^{\mathrm{Aa}}$ \\
\hline & 100 & $232.5 \pm 46.79 \mathrm{Bb}$ & $444.3 \pm 23.5^{\mathrm{Bc}}$ & $1.96 \pm 0.21 \mathrm{Ab}$ \\
\hline & 150 & $243.6 \pm 25.50^{\mathrm{Ba}}$ & $473.7 \pm 5.6^{\mathrm{Bb}}$ & $1.94 \pm 0.12 \mathrm{Ac}$ \\
\hline \multirow[t]{3}{*}{$\mathrm{CS}-\mathrm{Zn}$} & 50 & $252.9 \pm 42.20 \mathrm{Ac}$ & $486.4 \pm 26.8^{\mathrm{Ba}}$ & $1.92 \pm 0.11^{\mathrm{Ba}}$ \\
\hline & 100 & $276.3 \pm 19.89 \mathrm{Ab}$ & $544.8 \pm 24.5^{\mathrm{Ab}}$ & $1.90 \pm 0.13^{\mathrm{Bb}}$ \\
\hline & 150 & $347.3 \pm 34.55 \mathrm{Aa}$ & $622.0 \pm 19.5 \mathrm{Ac}$ & $1.76 \pm 0.07 \mathrm{Bc}$ \\
\hline \multirow[t]{2}{*}{ Zn source } & $\mathrm{ZnSO}_{4}$ & $235.8 \pm 31.03^{B}$ & $472.3 \pm 25.90^{B}$ & $1.98 \pm 0.46^{\mathrm{A}}$ \\
\hline & $\mathrm{CS}-\mathrm{Zn}$ & $292.2 \pm 51.93^{\mathrm{A}}$ & $551.1 \pm 22.27^{\mathrm{A}}$ & $1.86 \pm 0.53^{\mathrm{B}}$ \\
\hline \multirow[t]{3}{*}{ Added $\mathrm{Zn}$ level $\left(\mathrm{mg} \mathrm{kg}^{-1}\right)$} & 50 & $242.1 \pm 32.91^{b}$ & $492.7 \pm 13.21^{b}$ & $1.98 \pm 0.63^{a}$ \\
\hline & 100 & $254.4 \pm 41.21^{b}$ & $494.6 \pm 26.51^{b}$ & $1.93 \pm 0.34^{b}$ \\
\hline & 150 & $295.5 \pm 61.40^{\mathrm{a}}$ & $547.9 \pm 35.78^{a}$ & $1.85 \pm 0.85^{\mathrm{c}}$ \\
\hline \multirow[t]{3}{*}{$p$-value } & Zn source & $<0.001$ & $<0.001$ & $<0.001$ \\
\hline & Zn level & 0.001 & $<0.001$ & $<0.001$ \\
\hline & Interaction & 0.014 & $<0.001$ & $<0.001$ \\
\hline
\end{tabular}

ADG, average daily gain; ADFI, average daily feed intake; F/G, feed/gain ratio. ${ }^{A}, \mathrm{~B}$ Means comparison between the factor of $\mathrm{Zn}$ source within a column, values with different small letter superscripts mean significant difference $(p<0.05)$. $\mathrm{a}, \mathrm{b}, \mathrm{c}$ Means comparison between the factor of $\mathrm{Zn}$ level within a column, values with different small letter superscripts mean significant difference $(p<0.05)$.

In the present study, dietary $\mathrm{Zn}$ improved growth performance and decreased diarrhea incidence apparently; moreover, diets supplemented with CS-Zn were better than those supplemented with $\mathrm{ZnSO}_{4}$ in general. Buff et al. (2005) [21] reported that dietary supplementation of zinc-polysaccharide improved growth performance in weaned piglets. However, Case and Carlson (2002) [6] found that there was no significant difference in growth performance between the piglets fed $500 \mathrm{mg} \mathrm{kg}^{-1}$ of $\mathrm{Zn}$ as zinc-amino acid chelate and those of control group. Another study observed that organic zinc either as polysaccharide or proteinate complex had no effect on the growth performance [4]. The differences among the results may relate to the health level of trial animal, gene differential expression, breeding environment, feeding schedule, and especially, to differences in chelating agent. In recent years, domestic and international studies have reported that organic zinc increases the growth performance only in the growth stage, mainly to increase the feed intake [22]. In actual production, the addition of $\mathrm{Zn}$ to the diet of weaned piglets has the effect of promoting weight gain. One of the reasons is likely to be generated by participating in the taste element to affect the structure and function of oral mucosal epithelial cells. Moreover, $\mathrm{Zn}$ takes part in the synthesis of a variety of metabolic enzymes in the body, improves the digestion function, and enhances appetite. At the weaned stage, piglets suffer from one of the most stressful events, as they are fed with solid diets instead of liquid milk, which results in increased susceptibility to diarrhea. It was reported that zinc ion could inhibit the respiratory chain of pathogenic Escherichia coli, leading to diarrhea [22]. The results that CS-Zn reduced the incidence of diarrhea might depend on not only the function of zinc ion but also the antimicrobial activity of chelated chitosan. Another possible reason may be 
the improvement of the intestinal microflora and the immune function of weaned piglets fed diets containing CS-Zn [13]. The reduction in diarrhea may make a contribution to the improved growth performance.

A

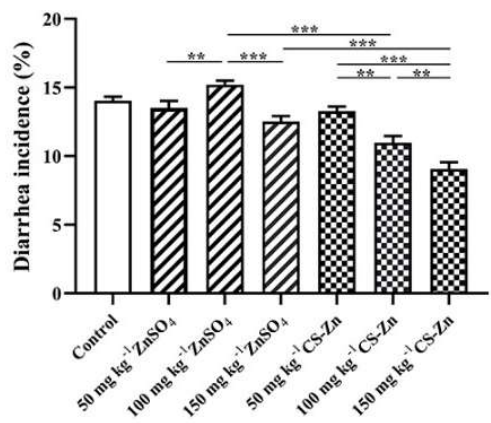

B

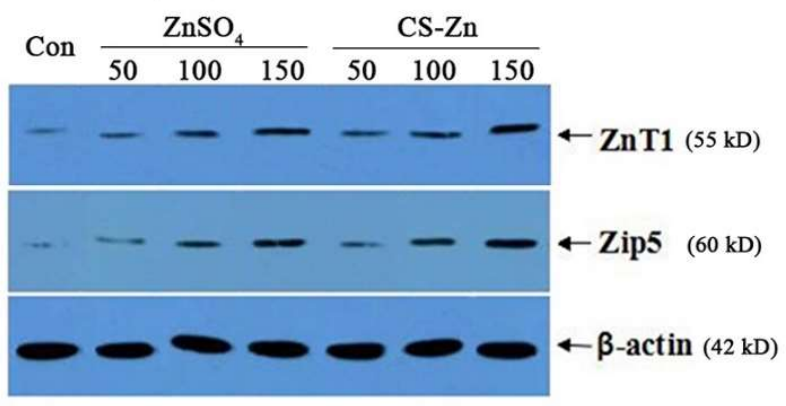

C

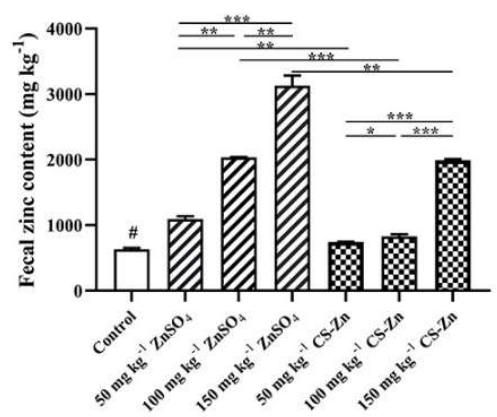

Figure 2. (A) Diarrhea incidence of weaned piglets fed dietary CS- $\mathrm{Zn}$ or $\mathrm{ZnSO}_{4}$. The columns represent means $\pm S D$. (B) Intestinal zinc transporters protein expression of weaned piglets fed dietary CS- $\mathrm{Zn}$ or $\mathrm{ZnSO}_{4}$. The bands are representative blots from one of the six pigs. The relative protein expression was expressed as the ratio of the target protein and $\beta$-action. (C) The zinc content in feces of weaned piglets fed dietary CS- $\mathrm{Zn}$ or $\mathrm{ZnSO}_{4}$. The columns represent means $\pm \mathrm{SD}$. ${ }^{*}$ Differences were considered significant at $p<0.05$. ${ }^{* *}$ Differences were considered significant at $p<0.01$. ${ }^{* * *}$ Differences were considered significant at $p<0.001$. "\#" Different from all supplemental Zn groups, $p<0.05$.

The effect of dietary $\mathrm{Zn}$ source and level on the content of $\mathrm{Zn}$ in the liver and pancreas of weaned piglets was shown in Table 3. Compared with the piglets fed the control diet, the piglets fed diets supplemented with $\mathrm{Zn}$ had higher $\mathrm{Zn}$ contents in the liver and pancreas $(p<0.05)$. The interaction between $\mathrm{Zn}$ source and added $\mathrm{Zn}$ level affected pancreas $\mathrm{Zn}$ content $(p<0.001)$, but had no effect on $\mathrm{Zn}$ content in the liver $(p=0.732)$. $\mathrm{Zn}$ source and added $\mathrm{Zn}$ level significantly affected $\mathrm{Zn}$ contents in the liver $(p<0.007)$. The piglets fed diets supplemented with CS- $Z n$ had higher $\mathrm{Zn}$ contents in the liver than those fed diets supplemented with $\mathrm{ZnSO}_{4}(p<0.05)$. Compared with $\mathrm{ZnSO}_{4}$, all levels of CS- $\mathrm{Zn}$ remarkably increased the zinc content in pancreas $(p<0.05)$. There were significant differences in the zinc content in pancreas among $50 \mathrm{mg} \mathrm{kg}^{-1}$ CS-Zn, $100 \mathrm{mg} \mathrm{kg}^{-1} \mathrm{CS}-\mathrm{Zn}$, and $150 \mathrm{mg} \mathrm{kg}^{-1} \mathrm{CS}-\mathrm{Zn}$ groups $(p<0.05)$, which was appropriate for $\mathrm{ZnSO}_{4}$ groups. The $\mathrm{Zn}$ contents in the liver and pancreas increased linearly with added $\mathrm{Zn}$ increasing $(p<0.001)$. The effects of dietary $\mathrm{Zn}$ source and level on the content of $\mathrm{Cu}$ in the liver 
and pancreas was shown in Table S3. The Zn source and added Zn level had no significant influence on the content of $\mathrm{Cu}$ in the liver, but had a significant effect on that in pancreas. The concentrations of pancreatic $\mathrm{Cu}$ in $50 \mathrm{mg} \mathrm{kg}^{-1}, 100 \mathrm{mg} \mathrm{kg}^{-1}$, and $150 \mathrm{mg} \mathrm{kg}^{-1} \mathrm{CS}-\mathrm{Zn}$ groups and the $150 \mathrm{mg} \mathrm{kg}^{-1} \mathrm{ZnSO}_{4}$ group were significantly increased, which was similar with the study of Hill et al. (2014) [23] who observed that adding organic zinc can increase the concentration of $\mathrm{Cu}$ in kidney. CS- $\mathrm{Zn}$ can not only affect the homeostasis of $\mathrm{Zn}$ metabolism in the pancreas, but also affect the metabolism of $\mathrm{Cu}$. While, $\mathrm{ZnSO}_{4}$ had a significant effect on $\mathrm{Cu}$ metabolism in the pancreas only when the dose of $\mathrm{ZnSO}_{4}$ reached $150 \mathrm{mg} \mathrm{kg}^{-1}$. Compared with the same dose of $\mathrm{ZnSO}_{4}, 50 \mathrm{mg} \mathrm{kg}^{-1}$ and $100 \mathrm{mg} \mathrm{kg}^{-1} \mathrm{CS}-\mathrm{Zn}$ significantly increased the copper content in the pancreas, indicating that CS- $\mathrm{Zn}$ reduced the competitive inhibitory effect of zinc and copper in the process of zinc absorption and transport.

Table 3. Effects of dietary $\mathrm{Zn}$ source and level on the content of $\mathrm{Zn}$ in the liver and pancreas of weaned piglets.

\begin{tabular}{|c|c|c|c|}
\hline Item & Added Zn Level (mg kg-1) & Liver $\mathrm{Zn}\left(\mathrm{mg} \mathrm{kg}^{-1}\right)$ & Pancreas $\mathrm{Zn}\left(\mathrm{mg} \mathrm{kg}^{-1}\right)$ \\
\hline Control & 0 & $70.83 \pm 9.29 *$ & $21.02 \pm 1.94 *$ \\
\hline \multirow[t]{3}{*}{$\mathrm{ZnSO}_{4}$} & 50 & $79.57 \pm 0.87$ & $38.13 \pm 0.88^{\mathrm{Bc}}$ \\
\hline & 100 & $99.52 \pm 1.38$ & $46.80 \pm 4.37^{\mathrm{Bb}}$ \\
\hline & 150 & $120.52 \pm 13.01$ & $66.04 \pm 4.31$ Ва \\
\hline \multirow[t]{3}{*}{$\mathrm{CS}-\mathrm{Zn}$} & 50 & $89.44 \pm 3.25$ & $43.82 \pm 3.76^{\mathrm{Ac}}$ \\
\hline & 100 & $106.53 \pm 2.95$ & $57.90 \pm 4.38 \mathrm{Ab}$ \\
\hline & 150 & $125.68 \pm 4.58$ & $91.65 \pm 3.93 \mathrm{Aa}$ \\
\hline \multirow[t]{2}{*}{ Zn source } & $\mathrm{ZnSO}_{4}$ & $99.87 \pm 18.76^{\mathrm{B}}$ & $52.57 \pm 13.04^{\text {B }}$ \\
\hline & CS-Zn & $107.22 \pm 15.81^{\mathrm{A}}$ & $65.93 \pm 21.06^{\mathrm{A}}$ \\
\hline \multirow[t]{3}{*}{ Added Zn level $\left(\mathrm{mg} \mathrm{kg}^{-1}\right)$} & 50 & $84.51 \pm 5.72^{c}$ & $40.97 \pm 4.00^{\mathrm{c}}$ \\
\hline & 100 & $103.02 \pm 4.32^{b}$ & $52.97 \pm 7.14^{b}$ \\
\hline & 150 & $123.10 \pm 9.44^{\mathrm{a}}$ & $77.68 \pm 13.94^{\mathrm{a}}$ \\
\hline \multirow[t]{5}{*}{$p$-value } & Zn source & 0.007 & $<0.001$ \\
\hline & Zn level & $<0.001$ & $<0.001$ \\
\hline & Interaction & 0.732 & $<0.001$ \\
\hline & Linear ${ }^{1}$ & $<0.001$ & $<0.001$ \\
\hline & Quadratic & 0.411 & 0.127 \\
\hline
\end{tabular}

${ }^{*}$ Different from all supplemental Zn groups, $p<0.05$. ${ }^{\mathrm{A}, \mathrm{B}}$ Means comparison between the factor of $\mathrm{Zn}$ source within a column, values with different small letter superscripts mean significant difference $(p<0.05)$. a,b,c Means comparison between the factor of $Z n$ level within a column, values with different small letter superscripts mean significant difference $(p<0.05) .{ }^{1}$ Linear effects of added Zn levels.

Figure 2B showed the intestinal zinc transporters protein expression of weaned piglets fed dietary CS- $\mathrm{Zn}$ or $\mathrm{ZnSO}_{4}$. Compared with control group, dietary zinc had a great effect on the protein expressions of ZnT1 and ZIP5 in duodenal mucosa $(p<0.05)$, while the protein expressions of ZnT1 in duodenal mucosa from CS-Zn treatment was enhanced than $\mathrm{ZnSO}_{4}$ treatment $(p<0.05)$ (Table 4$)$. The $\mathrm{Zn}$ source and added $\mathrm{Zn}$ level had significant influence on the protein expression of ZnT1 in duodenal mucosa $(p<0.001)$. The interaction between $\mathrm{Zn}$ source and added $\mathrm{Zn}$ level affected ZIP5 protein expression $(p<0.001)$. The protein expressions of ZIP5 in duodenal mucosa of piglets fed the diets supplemented with $100 \mathrm{mg} \mathrm{kg}^{-1} \mathrm{CS}-\mathrm{Zn}$ and $150 \mathrm{mg} \mathrm{kg}^{-1} \mathrm{CS}-\mathrm{Zn}$ treatments were higher than piglets from the same level of $\mathrm{ZnSO}_{4}$ treatments $(p<0.05)$, whereas there was no difference for that between the $50 \mathrm{mg} \mathrm{kg}^{-1} \mathrm{CS}-\mathrm{Zn}$ and $50 \mathrm{mg} \mathrm{kg}^{-1} \mathrm{ZnSO}_{4}$ groups $(p>0.05)$. Compared to the other two levels of $\mathrm{Zn}$, the dietary contained $150 \mathrm{mg} \mathrm{kg}^{-1} \mathrm{Zn}$, as both CS- $\mathrm{Zn}$ and $\mathrm{ZnSO}_{4}$ increased the expression of ZnT5 significantly. The protein expressions of ZnT1 and ZIP5 in duodenal mucosa increased linearly with the added $\mathrm{Zn}$ level increasing $(p<0.001)$. 
Table 4. Effects of dietary Zn source and level on the protein expressions of ZnT1 and ZIP5 in duodenal mucosa of weaned piglets.

\begin{tabular}{|c|c|c|c|}
\hline Item & Added Zn Level (mg kg $\left.{ }^{-1}\right)$ & ZnT1 & ZIP5 \\
\hline Control & 0 & $3.99 \pm 0.30 *$ & $2.99 \pm 0.34 *$ \\
\hline \multirow[t]{3}{*}{$\mathrm{ZnSO}_{4}$} & 50 & $7.84 \pm 0.56$ & $7.73 \pm 0.78^{c}$ \\
\hline & 100 & $13.50 \pm 0.84$ & $12.84 \pm 0.39 \mathrm{Bb}$ \\
\hline & 150 & $19.21 \pm 0.78$ & $19.71 \pm 0.54^{\mathrm{Ba}}$ \\
\hline \multirow[t]{3}{*}{$\mathrm{CS}-\mathrm{Zn}$} & 50 & $10.68 \pm 0.50$ & $8.42 \pm 0.70^{c}$ \\
\hline & 100 & $14.73 \pm 0.45$ & $15.59 \pm 0.53 \mathrm{Ab}$ \\
\hline & 150 & $21.15 \pm 0.75$ & $27.67 \pm 0.66^{\mathrm{Aa}}$ \\
\hline \multirow[t]{2}{*}{ Zn source } & $\mathrm{ZnSO}_{4}$ & $13.52 \pm 4.96^{\mathrm{B}}$ & $13.43 \pm 5.23^{B}$ \\
\hline & $\mathrm{CS}-\mathrm{Zn}$ & $15.52 \pm 4.60^{\mathrm{A}}$ & $17.23 \pm 8.45^{\mathrm{A}}$ \\
\hline \multirow[t]{3}{*}{ Added $\mathrm{Zn}$ level $\left(\mathrm{mg} \mathrm{kg}^{-1}\right)$} & 50 & $9.26 \pm 1.63^{c}$ & $8.08 \pm 0.76^{\mathrm{c}}$ \\
\hline & 100 & $14.11 \pm 0.90^{b}$ & $14.21 \pm 1.56^{b}$ \\
\hline & 150 & $20.18 \pm 1.26^{a}$ & $23.69 \pm 4.39^{\mathrm{a}}$ \\
\hline \multirow[t]{5}{*}{$p$-value } & Zn source & $<0.001$ & $<0.001$ \\
\hline & Zn level & $<0.001$ & $<0.001$ \\
\hline & Interaction & 0.150 & $<0.001$ \\
\hline & Linear & $<0.001$ & $<0.001$ \\
\hline & Quadratic & 0.365 & 0.240 \\
\hline
\end{tabular}

${ }^{*}$ Different from all supplemental Zn groups, $p<0.05$. ${ }^{\mathrm{A}, \mathrm{B}}$ Means comparison between the factor of $\mathrm{Zn}$ source within a column, values with different small letter superscripts mean significant difference $(p<0.05)$. ${ }^{\mathrm{a}, \mathrm{b}, \mathrm{c}}$ Means comparison between the factor of $\mathrm{Zn}$ level within a column, values with different small letter superscripts mean significant difference $(p<0.05)$.

Under normal physiological conditions, zinc is a charged bivalent cation, which cannot be transmitted through the cytoplasmic membrane or the endothelium by passive diffusion. Therefore, the transfer of zinc in the body requires a series of proteins to participate in the metabolism. The intestine is the site of excretion and absorption of zinc, which plays a crucial role in maintaining zinc homeostasis. The absorption of zinc in the intestine is shown as unsaturated and saturated kinetics, while the latter process requires a mediated carrier [24]. It is well known that there are two families of zinc transporter protein, the ZIP (SLC39) family and the ZnT (SLC30) family, which play opposite roles in homeostasis. Therefore, the expression of ZnT1 and ZIP5 protein in duodenal mucosa can reflect the ability of the body to absorb and transport $\mathrm{Zn}$ as CS- $\mathrm{Zn}$ or $\mathrm{ZnSO}_{4}$ and, then, deduce the bioavailability of CS-Zn. In the present study, the results showed that CS- $\mathrm{Zn}$ or $\mathrm{ZnSO}_{4}$ both increased the expression of zinc transporter protein, and the expression of zinc transporter protein increased linearly with supplemental zinc. ZnT1 is distributed on the basolateral membrane of enterocytes; the function of $\mathrm{ZnT1}$ is to transport excess intestinal zinc into extracellular matrix or organelles for the sake of reducing the zinc level of cytoplasm [25]. Increased zinc concentrations significantly elevated intestinal ZnT1 mRNA and protein expression [26]. The current study found that the $\mathrm{ZnT1}$ protein expressions in CS- $\mathrm{Zn}$ treatment were more elevated than that in $\mathrm{ZnSO}_{4}$ treatment and reached the highest expression in duodenal mucosa when adding $150 \mathrm{mg} \mathrm{Zn/kg}$. Liuzzi et al. (2004) [27] found that the mRNA expression abundance of ZnT1 was decreased in rats with zinc deficiency $\left(<1 \mathrm{mg} \mathrm{kg}^{-1}\right)$, while high zinc $\left(180 \mathrm{mg} \mathrm{kg}^{-1}\right)$ significantly increased the mRNA expression. ZIP5 is located on the basement membrane of the intestinal epithelial cells, which transports zinc through the basement membrane into the intestinal epithelial cells to maintain the zinc homeostasis. In the absence of zinc, the protein expression of ZIP5 was inhibited, and once the zinc concentration increased rapidly, it was involved in the protein translation process of ZIP5. The current study showed that the Zn source, added Zn level, and their interaction between $\mathrm{Zn}$ source and added $\mathrm{Zn}$ level had a significant influence on the protein expression of ZIP5 in duodenal mucosa. Weaver et al. (2007) [28] found that the mRNA expression of ZIP5 did not respond to zinc concentration, and zinc ion regulated the translation process of ZIP5 mRNA. Furthermore, the expression of zinc transporter protein in the CS- $\mathrm{Zn}$ group was higher than that in the $\mathrm{ZnSO}_{4}$ group, indicating that CS-Zn increased the protein expression of ZnT1 and ZIP5, so as to transport zinc to blood, facilitating the zinc transshipment to various tissues and organs. 
Relative bioavailability of CS-Zn based on multiple linear regression of zinc content in the liver and pancreas was shown in Table 5. Slope-ratio methodology was used to estimate relative bioavailability of CS- $\mathrm{Zn}$, with the relative bioavailability of $\mathrm{ZnSO}_{4}$ standard set at $100 \%$. Using the zinc content in the liver and pancreas as a response parameter, the bioavailability of CS-Zn was $110.9 \%(p<0.01)$ and $149.0 \%(p<0.01)$, respectively. The zinc content in feces of weaned piglets fed dietary CS- $\mathrm{Zn}$ or $\mathrm{ZnSO}_{4}$ is shown in Figure 2C. Compared with the same level of $\mathrm{Zn}$ as $\mathrm{ZnSO}_{4}$, the zinc contents in the feces of weaned piglets fed dietary CS-Zn were reduced by above 30\% $(p<0.05)$.

Table 5. Relative bioavailability of CS-Zn based on multiple linear regression of zinc content in the liver and pancreas.

\begin{tabular}{|c|c|c|c|c|c|}
\hline Item & Regression Equation & $\mathbf{R}^{2}$ & $p$ & $\mathrm{ZnSO}_{4}$ & CS-Zn \\
\hline Liver zinc content & $Y=68.747+0.366 X 1+0.330 X 2$ & 0.899 & 0.000 & $100 \%$ & $110.9 \%$ \\
\hline Pancreas zinc content & $Y=20.186+0.447 X 1+0.300 X 2$ & 0.953 & 0.000 & $100 \%$ & $149.0 \%$ \\
\hline
\end{tabular}

Note: X1 means the amount of $\mathrm{Zn}$ as CS-Zn added in the diet, $\mathrm{X} 2$ means the amount of $\mathrm{Zn}$ as $\mathrm{ZnSO}_{4}$ added in the diet.

Bioavailability is defined as the proportion of the ingested nutrients being absorbed and available for use or storage. Currently, researchers use the method of determining the accumulation of mineral elements in specific sensitive tissues to assess the bioavailability of mineral element additives. It is well known that the liver and pancreas are sensitive to zinc concentration in a diet [29]; therefore, zinc content in the liver and pancreas are used to estimate zinc bioavailability from different zinc sources. Cao et al. (2000) [30] estimated the bioavailability of polysaccharides-zinc chelate when compared with $\mathrm{ZnSO}_{4}$ via multiple linear regression slope-ratio analysis; the results were 110\% (liver) and 113\% (pancreas), respectively. The bioavailability of the current study was higher for CS-Zn compared with $\mathrm{ZnSO}_{4}$. Moreover, fecal zinc content of piglets fed CS- $\mathrm{Zn}$ was decreased significantly, which might be associated with the higher bioavailability of CS- $\mathrm{Zn}$ in body. Including all concentrations of CS- $\mathrm{Zn}$ groups and $\mathrm{ZnSO}_{4}$ groups increased zinc concentration in the liver significantly; moreover, there was a linear relationship between them. When the zinc supplementation exceeds the requirement of pigs, the liver zinc concentration is reduced inversely [23], indicating that zinc supplementation was not in excess in the current study. For weaned piglets, the normal digestive function of the pancreas is essential to maintain intestinal health and integrity. Pieper et al. (2015) [31] reported that the activity of intestinal digestive enzymes increased under the high concentration of zinc. Using the pancreas zinc concentration as an index, the present study showed that organic zinc sources had a higher bioavailability than inorganic sources. The results indicated that the pancreas was sensitive to the zinc concentration in a diet. The mechanism of absorption for CS- $\mathrm{Zn}$ in the small intestine has not yet been identified. The reason why the bioavailability of CS- $\mathrm{Zn}$ in weaned piglets is higher than that of $\mathrm{ZnSO}_{4}$ might be related to the absorption and metabolism mechanism of CS-Zn in the small intestine. In brief, CS-Zn harbors its own characters, accelerating the expression of ZnT1 and ZIP5 in the small intestine to increase the concentration of zinc in the liver and pancreas.

\section{Conclusions}

In summary, this study showed a facile and improved method for the synthesis of CS-Zn chelate, and the chelate developed a smaller size and coarser surface compared with CS. There were no lethal effects and pathological symptoms in mice. Weaned piglets fed dietary CS-Zn showed improved growth performance and decreased diarrhea incidence. Moreover, the bioavailability of CS- $\mathrm{Zn}$ was higher than that of $\mathrm{ZnSO}_{4}$ in piglets, and less fecal zinc was found in the pigs fed dietary CS-Zn. The results indicated that CS-Zn might be a potential substitution of inorganic zinc, reducing zinc excretion and, consequently, affecting the environment. Therefore, the present study might give evidence to further application possibilities of CS- $\mathrm{Zn}$ as a novel $\mathrm{Zn}$ source in animals and humans. Accordingly, CS-Zn will play a vital role in many fields to offer the chelate function of polysaccharides and metal. 
Supplementary Materials: The following are available online at https:/ /www.mdpi.com/article/10 .3390 /ani11092515/s1, Table S1. Analyzed Zn contents in diets for piglets (as fed basis), Table S2. The oral acute toxicity of CS-Zn in mice, Table S3. Effects of dietary Zn source and level on the content of $\mathrm{Cu}$ in liver and pancreas of weaned piglets.

Author Contributions: X.H. and X.M.: designed the experiments; X.M. and M.Q.: performed the experiments; T.X. and Z.Y.: analyzed the data; X.M.: wrote the manuscript, which was edited by M.Q., T.X., Z.Y., and X.H. All authors have read and agreed to the published version of the manuscript.

Funding: This work was financed by the National Science Foundation (31272477).

Institutional Review Board Statement: All methods in this study were carried out in accordance with the Guide for the Care and Use of Laboratory Animals prepared by the Institutional Animal Care and Use Committee of Zhejiang University, and animals used in this experiment were authorized by the principles of the Zhejiang University Animal Care and Use Committee (SYXK 2012-0178) and Experimental Animal Center of Zhejiang Province (SCXK 2014-0001).

Informed Consent Statement: Not applicable.

Data Availability Statement: The datasets analyzed in the present study are available from the corresponding author on reasonable request.

Conflicts of Interest: The authors declare that we have no conflict of interests.

$\begin{array}{ll}\text { Abbreviation } \\ \text { CS } & \begin{array}{l}\text { chitosan } \\ \text { chitosan-zinc chelated }\end{array} \\ \text { CS-Zn } & \text { National Research Council } \\ \text { NRC } & \text { atomic force microscopy } \\ \text { AFM } & \text { Fourier transform infrared } \\ \text { FT-IR } & \text { X-ray diffraction } \\ \text { XRD } & \text { acetic acid } \\ \text { AR } & \text { average daily gain } \\ \text { ADG } & \text { average daily feed intake } \\ \text { ADFI } & \text { feed to gain ratio } \\ \text { F/G } & \text { Slc 30 A 1 zinc transporter } \\ \text { ZIP1 } & \text { Slc 39 A 5 zinc transporter } \\ \text { ZIP5 } & \text { general linear model } \\ \text { GLM } & \text { least significant difference } \\ \text { LSD } & \text { analysis of variance } \\ \text { ANOVA } & \end{array}$

\section{References}

1. Liu, Y.; Espinosa, C.D.; Abeilla, J.J.; Casas, G.A.; Lagos, L.V.; Kwon, W.B.; Mathai, J.K.; Navarro, D.M.D.L.; Jaworski, D.W.; Stein, H.H. Non-antibiotic feed additives in diets for pigs-A review. Anim. Nutr. 2018, 4, 113-125. [CrossRef]

2. NRC. Nutrient Requirements of Swine, 11th ed.; National Academies Press: Washington, DC, USA, 2012.

3. Magdaleno, A.; Velez, C.G.; Wenzel, M.T.; Tell, G. Effects of cadmium, copper and zinc on growth of four isolated algae from a highly polluted argentina river. Bull. Environ. Contam. Toxical. 2014, 92, 202-207. [CrossRef] [PubMed]

4. Carlson, M.S.; Boren, C.A.; Wu, C.; Huntington, C.E.; Bollinger, D.W.; Veum, T.L. Evaluation of various inclusion rates of organic zinc either as polysaccharide or proteinate complex on the growth performance, plasma, and excretion of nursery pigs. J. Anim. Sci. 2004, 82, 1359-1366. [CrossRef] [PubMed]

5. Yazdankhah, S.; Rudi, K.; Bernhoft, A. Zinc and copper in animal feed-Development of resistance and co-resistance to antimicrobial agents in bacteria of animal origin. Microb. Ecol. Health Dis. 2014, 25. [CrossRef] [PubMed]

6. Case, C.L.; Carlson, M.S. Effect of feeding organic and inorganic sources of additional zinc on growth performance and zinc balance in nursery pigs. J. Anim. Sci. 2002, 80, 1917-1924. [CrossRef] [PubMed]

7. Sargin, I.; Kaya, M.; Arslan, G.; Baran, T.; Ceter, T. Preparation and characterisation of biodegradable pollen-chitosan microcapsules and its application in heavy metal removal. Bioresour. Technol. 2015, 177, 1-7. [CrossRef] [PubMed]

8. Kanmani, P.; Aravind, J.; Kamaraj, M.; Sureshbabu, P.; Karthikeyan, S. Environmental applications of chitosan and cellulosic biopolymers: A comperhensive outlook. Bioresour. Technol. 2017, 242, 295-303. [CrossRef] [PubMed]

9. Rhoades, J.; Gibson, G.; Formentin, K.; Beer, M.; Rastall, R. Inhibition of the adhesion of enteropathogenic Escherichia colistrains to HT-29 cells in culture by chito-oligosaccharides. Carbohydr. Polym. 2006, 64, 57-59. [CrossRef] 
10. Guo, Z.Y.; Ren, J.M.; Dong, F.; Wang, G.; Li, P.C. Comparative Study of the Influence of Active Groups of Chitosan Derivatives on Antifungal Activity. J. Appl. Polym. Sci. 2013, 127, 2553-2556. [CrossRef]

11. Jeong, Y.I.; Kim, D.H.; Chung, K.D.; Kim, Y.H.; Lee, Y.S.; Choi, K.C. Antitumor Activity of Trigonelline-Incorporated Chitosan Nanoparticles. J. Nanosci. Nanotechnol. 2014, 14, 5633-5637. [CrossRef]

12. Wang, X.H.; Du, Y.M.; Liu, H. Preparation, characterization and antimicrobial activity of chitosan-Zn complex. Carbohyd. Polym. 2004, 56, 21-26. [CrossRef]

13. Han, X.Y.; Ma, Y.F.; Lv, M.Y.; Wu, Z.P.; Qian, L.C. Chitosan-zinc chelate improves intestinal structure and mucosal function and decreases apoptosis in ileal mucosal epithelial cells in weaned pigs. Br. J. Nutr. 2014, 111, 1405-1411. [CrossRef]

14. Kirby, A.R.; MacDougall, A.J.; Morris, V.J. Atomic force microscopy of tomato and sugar beet pectin molecules. Carbohydr. Polym. 2008, 71, 640-647. [CrossRef]

15. Saeed, S.E.; EI-Molla, M.M.; Hassan, M.L.; Bakir, E.; Abdel-Mottaleb, M.M.S.; Abdel-Mottaleb, M.S.A. Novel chitosan-ZnO based nanocomposites as luminescent tags for cellulosic materials. Carbohydr. Polym. 2014, 99, 817-824. [CrossRef] [PubMed]

16. Guo, M.; Diao, P.; Cai, S. Hydrothermal growth of well-aligned ZnO nanorod arrays: Dependence of morphology and alignment ordering upon preparing conditions. J. Solid State Chem. 2005, 178, 1864-1873. [CrossRef]

17. AbdElhady, M.M. Preparation and Characterization of Chitosan/Zinc Oxide Nanoparticles for Imparting Antimicrobial and UV Protection to Cotton Fabric. Int. J. Carbohydr. Chem. 2012, 2012, 840591. [CrossRef]

18. Anadhavelu, S.; Thambidurai, S. Preparation of chitosan-zinc oxide complex during chitin deacetylation. Carbohydr. Polym. 2011 83, 1565-1569. [CrossRef]

19. Li, L.H.; Deng, J.C.; Deng, H.R.; Liu, Z.L.; Xin, L. Synthesis and characterization of chitosan/ZnO nanoparticle composite membranes. Carbohydr. Res. 2010, 345, 994-998. [CrossRef]

20. Trimukhe, K.D.; Varma, A.J. A morphological study of heavy metal complexes of chitosan and crosslinked chitosans by SEM and WAXRD. Carbohydr. Polym. 2008, 71, 698-702. [CrossRef]

21. Buff, C.E.; Bollinger, D.W.; Ellersieck, M.R.; Brommelsiek, W.A.; Veum, T.L. Comparison of growth performance and zinc absorption, retention, and excretion in weanling pigs fed diets supplemented with zinc-polysaccharide or zinc oxide. J. Anim. Sci. 2005, 83, 2380-2386. [CrossRef]

22. Madec, F.; Bridoux, N.; Bounaix, S.; Cariolet, R.; Duval-lflah, Y.; Hampson, D.J.; Jestin, A. Experimental models of porcine post-weaning colibacillosis and their relationship to post-weaning diarrhoea and digestive disorders as encountered in the field. Vet. Microbiol. 2000, 72, 295-310. [CrossRef]

23. Hill, G.M.; Mahan, D.C.; Jolliff, J.S. Comparison of organic and inorganic zinc sources to maximize growth and meet the zinc needs of the nursery pig. J. Anim. Sci. 2014, 92, 1582-1594. [CrossRef] [PubMed]

24. Falcon-Perez, J.M.; Dell'Angelica, E.C. Zinc transporter 2 (SLC30A2) can suppress the vesicular zinc defect of adaptor protein 3-depleted fibroblasts by promoting zinc accumulation in lysosomes. Exp. Cell Res. 2007, 313, 1473-1483. [CrossRef] [PubMed]

25. Gefeller, E.M.; Martens, H.; Aschenbach, J.R.; Klingspor, S.; Twardziok, S.; Wrede, P.; Pieper, R.; Lodemann, U. Effects of age and zinc supplementation on transport properties in the jejunum of piglets. J. Anim. Physiol. Anim. Nutr. 2015, 99, 542-552. [CrossRef] [PubMed]

26. Yu, Y.Y.; Kirschke, C.P.; Huang, L. Immunohistochemical analysis of ZnT1, 4, 5, 6, and 7 in the mouse gastrointestinal tract. J. Histochem. Cytochem. 2007, 55, 223-234. [CrossRef]

27. Liuzzi, J.P.; Cousins, R.J. Mammalian zinc transporters. Annu. Rev. Nutr. 2004, 24, 151-172. [CrossRef]

28. Weaver, B.P.; Beattie, J.D.; Kambe, T.; Andrews, G.K. Novel zinc-responsive post-transcriptional mechanisms reciprocally regulate expression of the mouse Slc39a4 and Slc39a5 zinc transporters (Zip4 and Zip5). Biol. Chem. 2007, 388, 1301-1312. [CrossRef]

29. Payne, R.L.; Bidner, T.D.; Fakler, T.M.; Southem, L.L. Growth and intestinal morphology of pigs from sows fed two zinc sources during gestation and lactation. J. Anim. Sci. 2006, 84, 2141-2149. [CrossRef]

30. Cao, J.; Henry, P.R.; Guo, R.; Holwerda, R.A.; Toth, J.P.; Littell, R.C.; Miles, R.D.; Ammerman, C.B. Chemical characteristics and relative bioavailability of supplemental organic zinc sources for poultry and ruminants. J. Anim. Sci. 2000, 78, 2039-2054. [CrossRef]

31. Pieper, R.; Martin, L.; Schunter, N.; Tudela, C.V.; Weise, C.; Klopfleisch, R.; Zentek, J.; Einspanier, R.; Bondzio, A. Impact of high dietary zinc on zinc accumulation, enzyme activity and proteomic profiles in the pancreas of piglets. J. Trace Elem. Med. Biol. 2015, 30, 30-36. [CrossRef] 